\title{
A 17-cm endoscopic submucosal tunnel dissection for esophageal cancer and insertion of polyglycolic acid-coated stent
}

A 58-year-old man was referred to our hospital because of the large extent of his esophageal cancer. Gastroendoscopy with iodine staining showed a $17-\mathrm{cm}$ long circumferential lesion.

An endoscopic submucosal tunnel dissection (ESTD) procedure was performed ( $\triangleright$ Video 1). First, the margins were checked. Submucosal injection and circumferential incision were done at the proximal margin. The distal margin was also injected and incised. Submucosal tunnel dissection was done from the oral side to the anal side in all four directions. Lateral resection was performed using both the IT2 knife (KD-611L; Olympus, Japan) and a dual knife (KD-650Q; Olympus). When fibrotic lesions were encountered, the SB knife (Sumitomo Bakelite, Japan) was used. With repeated injections and dissections, the anal side was finally reached, and the remnant lesion was cut.

Self-expandable fully covered stents (M.I. Tech, Pyeongtaek-si. Gyeonggi-do, Korea) were coated with polyglycolic acid (PGA) sheets (Neoveil; Gunze, Kyoto, Japan). In this patient, the two PGAcoated stents were placed to make a continuous length.

- Fig. 1 presents details of the esophageal cancer specimen resulting from the entire circumferential resection.

The procedure took 6 hours with the patient under general anesthesia and there were no immediate complications. The stents were removed after 2 months ( $\vee$ Fig. 2 a). No severe stricture was seen at gastroendoscopy 4 months after ESTD ( Fig. 2 b).

Circumferential esophageal lesions are usually treated by ESTD [1]. However, postoperative esophageal stricture is the most common concern following very extensive ESTD [2]. Repeated endoscopic balloon dilations and steroid injection have been the standard treat-

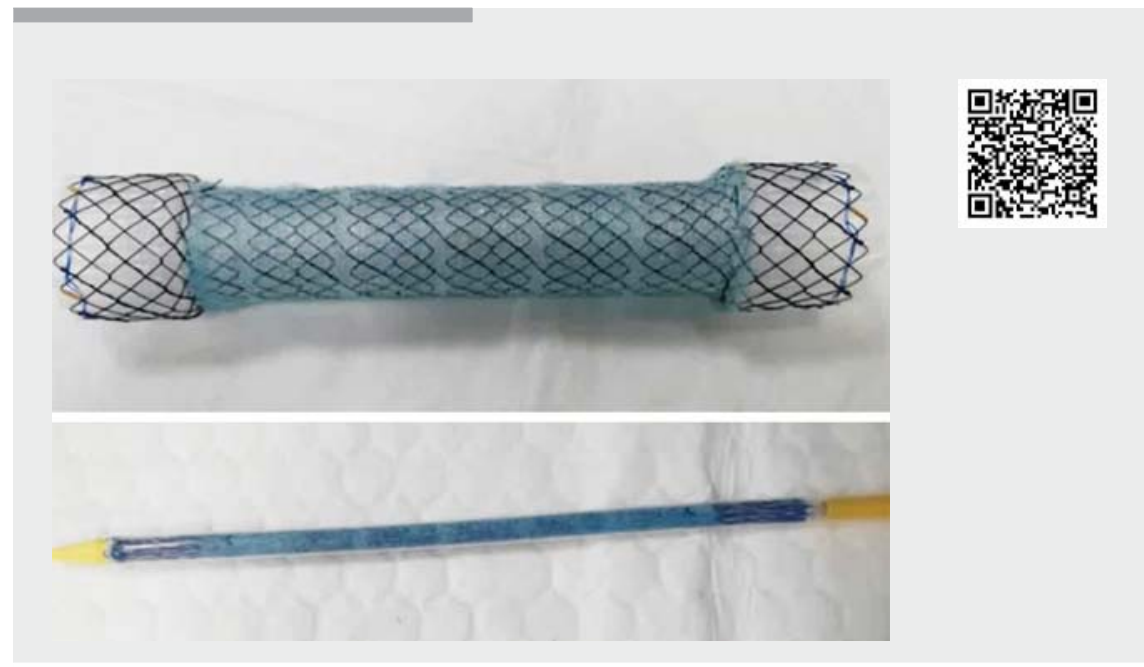

$\checkmark$ Video 1 A 17-cm endoscopic submucosal tunnel dissection of circumferential esophageal cancer, and placement of polyglycolic acid (PGA)-coated stents.
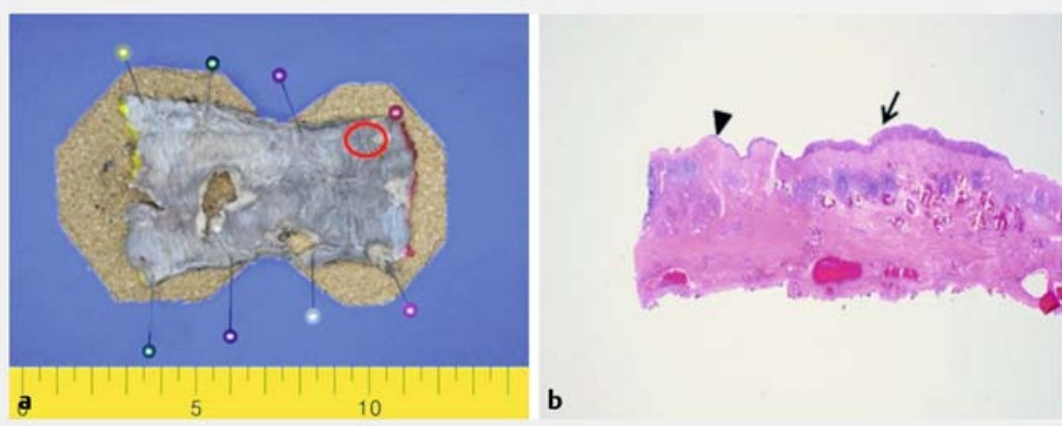

- Fig. 1 a Final specimen after $17-\mathrm{cm}$ long endoscopic submucosal tunnel dissection (ESTD) of a circumferential esophageal cancer. $\mathbf{b}$ The tumor is composed of extensive squamous cell carcinoma in situ (arrow) and focal invasive squamous cell carcinoma (arrowhead; red circle in a).

ment for postoperative esophageal strictures $[3,4]$. The PGA material has been marketed as a biodegradable synthetic suture. In previous studies, it has been speculated that PGA protects the wound surface from contact with exogenous materials, helps subsequent organization of the granulation tissue, and results in less cicatrization [5]. Our case explored the attractive option of using a PGA-coated stent to prevent esophageal stricture, even in a $17-\mathrm{cm}$ long esophageal ESTD.

Endoscopy_UCTN_Code_TTT_1AO_2AG 


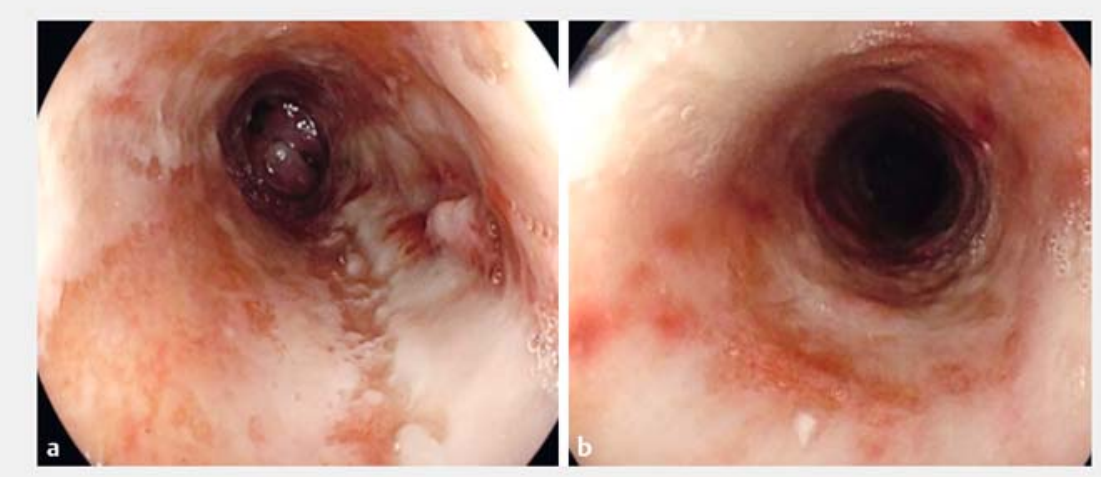

- Fig. 2 a After stent removal at 2 months, endoscopy showed hyperemic and edematous esophageal mucosa, but no severe stricture. b At 4 months after ESTD, the esophageal mucosa was healing and no evidence of esophageal stricture formation was noted.

\section{Competing interests}

The authors declare that they have no conflicts of interest or funding sources, including pharmaceutical and industry support, that require acknowledgment.

The authors

In Kyung Yoo*, Min Kang Seo*, Sung Pyo Hong, Hyojung Lee, Joo Young Cho

Division of Gastroenterology, Department of Internal Medicine, Cha Bundang Medical Center, Seongnam, Korea

\footnotetext{
* These authors contributed equally to this work.
}

\section{Corresponding author}

\section{Joo Young Cho, MD, PhD}

Division of Gastroenterology, Department of Internal Medicine, Cha Bundang Medical Center, 59 Yatapro, Bundang-gu,

Seongnam-si, Korea

Fax: +82-32-7805005

cjy6695@naver.com

\section{References}

[1] Linghu E, Feng X, Wang X et al. Endoscopic submucosal tunnel dissection for large esophageal neoplastic lesions. Endoscopy 2013; 45: 60-62

[2] Ono S, Fujishiro M, Niimi K et al. Predictors of postoperative stricture after esophageal endoscopic submucosal dissection for superficial squamous cell neoplasms. Endoscopy 2009; 41: 661-665
[3] Wong VW, Teoh AY, Fujishiro M et al. Preemptive dilatation gives good outcome to early esophageal stricture after circumferential endoscopic submucosal dissection. Surg Laparosc Endosc Percutan Tech 2010; 20: e25-e27

[4] Hanaoka N, Ishihara R, Takeuchi Y et al. Intralesional steroid injection to prevent stricture after endoscopic submucosal dissection for esophageal cancer: a controlled prospective study. Endoscopy 2012; 44: $1007-1011$

[5] Takeuchi J, Suzuki H, Murata M et al. Clinical evaluation of application of polyglycolic acid sheet and fibrin glue spray for partial glossectomy. J Oral Maxillofac Surg 2013; 71: e126-e131

\section{Bibliography}

DOI https://doi.org/10.1055/a-0978-4724

Published online: 21.8.2019

Endoscopy 2020; 52: E29-E30

(c) Georg Thieme Verlag KG

Stuttgart · New York

ISSN 0013-726X

\section{ENDOSCOPY E-VIDEOS}

https://eref.thieme.de/e-videos

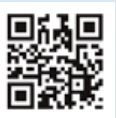

Endoscopy E-Videos is a free access online section, reporting on interesting cases and new techniques in gastroenterological endoscopy. All papers include a high quality video and all contributions are freely accessible online.

This section has its own submission website at

https://mc.manuscriptcentral.com/e-videos 